\title{
Trajetórias religiosas de jovens sem religião - algumas implicações para o debate sobre desinstitucionalização
}

Sílvia Fernandes*

\section{Resumo}

Nas últimas duas décadas têm crescido o número de pessoas que se declaram sem religião. Quando são analisados os diversos segmentos sociais a partir de bases censitárias, é entre a juventude que se encontram os maiores índices dos que assumem essa autoidentidade. 0 fenômeno da desinstitucionalização religiosa passou a ser mais estudado a partir do penúltimo censo brasileiro realizado em 2000 , que totalizou $7,4 \%$ da população brasileira declarando-se sem religião, o que representou um crescimento de aproximadamente $3 \%$ em uma década. Em 2010, os sem religião na população brasileira passaram a ser $8 \%$, mas entre os jovens com idade entre 15 a 29 anos esse número chega a 10,1\%. Este artigo objetiva compreender a trajetória de três jovens brasileiros sem religião, ex-evangélicos residentes em regiões periféricas do Estado do Rio de Janeiro, onde predominam as igrejas evangélicas de corte pentecostal e neopentecostal. Discute-se o processo de construção da identidade juvenil cuja dinâmica rejeita a religião institucionalizada, e analisam-se as percepções desses jovens sobre tal processo.

\section{Palavras-chave}

Juventude sem religião. Ateísmo. Agnosticismo. Desinstitucionalização.

\section{Abstract}

In the last two decades, the number of people who declare themselves non-religious has grown. When the diverse social segments from censitary bases are analyzed, the highest rates of those who take on this self-identity is among the youth. The phenomenon of religious deinstitutionalization started to be studied in the next to last Brazilian census carried out in 2000 , in which a total of $7.4 \%$ of the Brazilian population declared to be non-religious,

\footnotetext{
* Sílvia Fernandes é socióloga e professora associada do Departamento de Ciências Sociais, da UniversidadeFederal Rural do Rio deJaneiro(UFRRJ).E-mail: silviafernandes@ufrrj.br.ORCID: https://orcid.org/0000-0001-7951-7931.
} 
representing a growth of approximately $3 \%$ in one decade. In 2010, the non-religious in the Brazilian population reached $8 \%$, but among young people aged from 15 to 29 , the numbers reach $10,1 \%$. The goal of this article is to comprehend the trajectories of three non-religious young Brazilians, who live in the peripheral areas of the state of Rio de Janeiro. The process of the construction of youth identity, where the dynamic tends to reject the institutionalized religion, is discussed Finally, using youth discourses on moral, political and religious issues, the article problematizes the use of the "conservatism" category, proposing analytical nuances.

\section{Keywords}

Non-religious Youth. Atheism, Agnosticism. Deinstitutionalization.

\section{Introdução}

Desde a liberação dos resultados do censo 2000, a necessidade de compreender quem são os sem religião no Brasil tem pautado um conjunto de investigações. Vários pesquisadores (ROGRIGUES, 2010; NOVAES, 2006, 2013; FERNANDES, 2008; 2013; MONTERO; DULLO, 2014; CAMURÇA, 2017) debruçaram-se sobre o tema trazendo chaves de leitura interessantes a respeito dos modos de ser sem religião no país.

Cinco anos após a liberação dos resultados do censo, foi realizada uma pesquisa nacional sobre mudança de religião no Brasil $^{1}$ em que se constatou haver $7,8 \%$ de pessoas que se declaravam sem religião. $\mathrm{Na}$ ocasião, duas características dos sem religião foram identificadas: 1) os

\footnotetext{
${ }^{1}$ Trata-se de uma pesquisa realizada em 50 municípios brasileiros com uma amostra de 2.870 entrevistados. O objetivo do estudo foi compreender o movimento de mudança de religião no país, sobretudo a partir das motivações dos indivíduos para tal circulação entre diferentes denominações religiosas ou para assumirem a identidade de sem religião. Na ocasião, constatou-se que $24 \%$ dos entrevistados já haviam mudado de religião ao menos uma vez na vida, sendo o "bem-estar", propiciado pela nova religião, e a "aproximação com Deus" os principais motivos para a ocorrência do trânsito religioso. A pesquisa totalizou os seguintes índices: $67,2 \%$ de católicos; $4,1 \%$ de evangélicos históricos; $13,9 \%$ de evangélicos pentecostais e neopentecostais; $3,4 \%$ foram classificados em religiões minoritárias categorizadas como "outras religiões"; 3,5\% pertenciam a uma religião que não pôde ser determinada, por exemplo, "Bíblia" ou "católico-espírita", dentre outras, e, por fim, 7,8\% declararam-se sem religião/ateu.
} 
sem religião no país não se constituem exclusivamente como arreligiosos; 2) a desinstitucionalização religiosa não seria necessariamente um processo irreversível (FERNANDES, 2006, 2008, 2012). Além disso, considerou-se importante criar tipologias para os indivíduos sem religião que emergiam nos resultados: 1 . sem religião de religiosidade própria; 2 . desvinculados e descrentes; 3. críticos das religiões; 4 . ateus; 5. destradicionalizados. Cada uma dessas tipologias foi explorada à época em sua complexidade e inovação (FERNANDES, 2008). Não obstante, acredita-se que um estudo da mesma natureza nos tempos atuais alargaria as possibilidades de tipificação e demandaria a agregação de outros fatores promotores do abandono institucional ou da elasticidade de vínculo.

Na ocasião, a partir da classificação realizada, evidenciava-se que a identidade religiosa dos sem religião, por um lado, era constituída por motivos muito pragmáticos, e, por outro, não representava um necessário ceticismo. Desse modo, a simples "falta de tempo" dos tempos modernos era acionada pelas pessoas como um dispositivo justificador de sua identidade religiosa sem vínculos, mas não necessariamente sem crenças. Em contrapartida, a complexidade estava exatamente na consideração de que um viés muito religioso, pautado em crenças, sobretudo cristãs, ainda orientava os novos desinstitucionalizados religiosamente.

O estudo quantitativo supracitado (FERNANDES, 2006) confirmava o ecletismo de um país majoritariamente católico, de cultura cristã fortemente engendrada nas práticas e maneiras de representar o mundo e colocava como uma necessidade imediata explorar qualitativamente o perfil de indivíduos sem religião no país. Desse modo, foi realizada uma ampla pesquisa qualitativa em São Paulo, Rio de Janeiro, Belo Horizonte, Porto Alegre, Recife e Salvador (FERNANDES, 2009)², em um esforço por construir o perfil desses indivíduos nas grandes cidades e o seu modus vivendi em relação à participação sociopolítica e religiosa qualitativa A análise das entrevistas nesse estudo das seis grandes cidades possibilitou constatar ao menos dois movimentos em relação aos sem religião residentes em camadas populares daquelas cidades: a) a existência de uma heterogeneidade da crítica ao religioso ou aos pressupostos religiosos; b) o enfraquecimento

\footnotetext{
${ }^{2}$ Trata-se de uma pesquisa qualitativa que mapeou crenças e práticas religiosas e sociopolíticas de membros da Assembleia de Deus (130 pessoas); Comunidades Eclesiais de Base (72 pessoas) e indivíduos sem religião (72 pessoas), totalizando 434 entrevistas em profundidade.
} 
da transmissão religiosa intergeracional. Por sua vez, nas camadas médias identificou-se uma abordagem mais racionalista, em que os indivíduos pesquisados discordavam de preceitos religiosos e demonstravam rejeição ao discurso religioso, muitas vezes por eles compreendido como fonte de alienação (FERNANDES, 2009, p.416-417).

Um estudo de fôlego, a partir de microdados do IBGE (JACOB et al., 2003) desvendou o perfil sociológico dos sem religião no Brasil. Eles são majoritariamente pobres e jovens contrariando expectativas dos analistas. A partir dessa constatação, tornou-se pertinente a realização de uma abordagem qualitativa para entender a relação entre periferia e desinstitucionalização religiosa, uma vez que a expansão do pentecostalismo nas camadas populares grafou vários pontos de interrogação em nossa agenda ao nos depararmos com jovens sem religião e periféricos, que não necessariamente acionavam os bens simbólicos oferecidos pelo pentecostalismo e permaneciam nas igrejas evangélicas.

Considerando sero Brasil majoritariamentecatólico, a maioria das pessoas que se declaram sem religião é naturalmente procedente do catolicismo. No entanto, a pesquisa nacional citada inicialmente identificou que cerca de $24 \%$ dos que se declaravam sem religião pertenceram anteriormente a alguma igreja evangélica (FERNANDES, 2006). Sendo assim, pode haver um passado institucional religioso que compõe a trajetória daqueles que na atualidade se assumem como sem religião, ateus ou agnósticos. O presente texto resulta de uma pesquisa qualitativa mais ampla, ainda em andamento, com jovens sem religião, ateus e agnósticos residentes no estado do Rio de Janeiro, especialmente em regiões periféricas. ${ }^{3}$ Estão sendo realizadas entrevistas em profundidade visando conhecer suas visões acerca da religião, da política e de temas relacionados a moralidades. Que discursos, crenças e visões de mundo esses jovens evangélicos oriundos de igrejas

\footnotetext{
${ }^{3}$ A pesquisa em desenvolvimento intitulada: “Vínculos e (im) permanências - religião e política em segmentos juvenis conta com o apoio da FAPERJ - Fundação de Amparo à Pesquisa do Rio de Janeiro. Até setembro de 2018 foram entrevistados 50 jovens sem religião, ateus e agnósticos no Estado do Rio de Janeiro. Agradecemos aos bolsistas de IC/FAPERJ - Ana Raquel Pereira da Silva; PIBIC/ CNPq - Bruno Souza; PIBIC/CNPq - Matheus Soares da Conceição pela realização, transcrição e análise preliminar das entrevistas. Agradecemos ainda aos membros do DT- Crelig - Grupo de Pesquisa - Dinâmicas Territoriais, Cultura e Religião que atuaram debatendo a bibliografia pertinente.
} 
pentecostais ou neopentecostais assumem ao tornarem-se respectivamente agnóstico, ateu e sem religião?

Faremos aqui uma análise exploratória da trajetória de três jovens, exevangélicos que atualmente se declaram, respectivamente, agnóstico, ateu e sem religião. $\mathrm{O}$ critério de escolha desses jovens para este artigo foi que seus respectivos vínculos de origem aconteceram em Igrejas evangélicas. O número de casos não permite realizar generalizações, mas antes suscitar perguntas que venham a contribuir para estudos posteriores.

O dado empírico mostra que o processo de mobilidade religiosa pode ser composto por uma saída da religião, ainda que de maneira provisória. $\mathrm{O}$ fato de alguns jovens, sobretudo evangélicos, serem considerados "desviados" por parte das lideranças religiosas não se configuraria necessariamente como um dado novo. No entanto, cabe observar que, quando esses jovens se declaram sem religião, algo parece mudar no modo como se percebem diante da instituição religiosa, denotando que seu percurso segue uma direção mais autônoma e descolada da avaliação que as igrejas possuem deles, ainda que um novo vínculo, no futuro, possa não ser completamente descartado.

\section{Desinstitucionalização e desvinculação}

Adotamos como sinônimos os termos desinstitucionalização (BROWN, 1977) e desvinculação tendo como parâmetro a ausência de vínculos institucionais. Referimo-nos, portanto, ao processo que se desenvolve na esfera das identidades pessoal e social e que leva determinados indivíduos a se declararem sem vínculo ou não pertencentes a instituições religiosas. Não se trata, portanto, de analisar uma condição de pertencimento na qual haveria vínculos religiosos mais flexíveis, porém não ao ponto de gerarem impacto na autodeclaração (por exemplo, o "católico não praticante", no caso da esfera religiosa). Mas ao contrário, temos em conta as situações nas quais a desvinculação produz um impacto direto na autodeclaração do jovem desinstitucionalizado que assume publicamente - como visto nos censos - uma condição mais autônoma diante das instituições, rejeitandoas ou relativizando sua validade como mediadoras para o exercício das diferentes práticas sociais nas esferas aqui retratadas, a saber, religião e política.

Consideramos os processos de desinstitucionalização religiosa que produzem especificamente três tipos de autodeclaração dos jovens às 
pesquisas censitárias: agnóstico, ateu e sem religião, independentemente do sexo declarado (feminino ou masculino). A desinstitucionalização religiosa seria um sintoma de nossa época, marcada pela diferenciação e experimentação individual, ainda que consideradas as variações contextuais em diferentes territórios. Por outro lado, esse tipo de desinstitucionalização ocorre paralelamente ao pluralismo religioso, que pode ser entendido como uma variação da sociedade secular (BENDER, 2013), uma vez que a liberdade advinda da secularização foi o agente catalisador de diferentes modelos e expressões do pluralismo.

Com efeito, a chamada diversidade das sociedades modernas supõe tanto a multiplicidade de movimentos, igrejas, grupos e experiências religiosas quanto a desinstitucionalização, o ceticismo, a recomposição identitária numa perspectiva ateísta e muitas outras variações integradas ao processo de afastamento dos indivíduos das instituições de referência.

Embora o fenômeno de desinstitucionalização religiosa esteja presente no país em todos os segmentos populacionais, verifica-se sua expressão mais aguda entre os jovens. Sendo assim, se considerados os diferentes extratos etários, nota-se que na faixa de 15 a 29 anos há a maior proporção de pessoas que se declaram sem religião, totalizando $10,1 \%$ dos jovens nessa faixa, conforme o último censo do IBGE - Instituto Brasileiro de Geografia e Estatística. Nesse mesmo censo, os que se declararam sem religião na população brasileira totalizavam $8 \%$.

Esse dado justifica a escolha desse segmento etário como objeto de investigação de longa duração, perseguindo suas características, tipos e variações, em consonância com um conjunto de estudos que tratam da relação do jovem com a religião e com a política (FERNANDES, 2008-2014). Os números censitários demonstram ainda que o Estado do Rio de Janeiro concentra o maior percentual de pessoas sem religião, chegando a $15 \%$. Na faixa etária de 15 a 29 anos, o índice chega a 19,8\% de acordo com o censo 2010. Para efeito de uma primeira definição, considere-se - a partir de estudos anteriores (FERNANDES, 2009, 2011) - que, em geral, jovens sem religião tendem a possuir determinadas crenças religiosas, embora sem vínculos ou pertenças institucionais; os ateus, por sua vez, além de não estarem vinculados a instituições de natureza religiosa, não possuem crenças advindas desse universo. Os estudos sobre jovens agnósticos são muito raros no Brasil, mas cabe buscar entender como a categoria é acionada pelos jovens que assim se autodeclaram.

Destaque-se que o agnosticismo sustenta a impossibilidade de se 
comprovar a existência e a inexistência de Deus por meios racionais seguindo a tradição do naturalista Thomas Huxley (LOMBRAÑA, 2011). $\mathrm{O}$ censo brasileiro distingue os índices dentro do grande grupo presente na grande categoria "sem religião". Assim, a categoria censitária "sem religião" no segmento juvenil em questão é composta por sem religião $(9,6$ $\%)$, ateus $(0,43 \%)$ e agnósticos $(0,09 \%)$, totalizando o índice anteriormente apontado nessa grande categoria sem religião (10,1\%).

Sublinhe-se que há distinções interessantes na grande categoria sem religião. Os ateus configuram um grupo clássico que tem origem desde a Antiguidade e adquire diferentes conotações ao longo da história. Segundo Armstrong (1999), na contemporaneidade, o significado desse segmento estaria relacionado à crítica moderna da religião de modo mais estrito, com fortalecimento a partir das teorias do século $\mathrm{XX}$, tais como o marxismo e a psicologia Freudiana. No Brasil, os ateus têm tomado de empréstimo o vocabulário político de certos grupos minoritários, como negros e mulheres, e muitas vezes consideram-se perseguidos por religiosos (MONTERO; DULLO, 2014).

Se consideradas a desvinculação e a crítica mais intensa às instituições como uma tendência de época - cujos efeitos são também perceptíveis nas esferas religiosa e política -, vislumbra-se a hipótese de que há sedimentações socioculturais que se originam em contexto familiar e a expandem-se a partir dele. Os jovens das novas gerações estariam passando, portanto, por um tipo de ruptura, adesão e/ou relativização de valores políticos e religiosos de seus pais.

O fenômeno da ruptura pode ser compreendido como uma crise de transmissão geracional (TAVARES; CAMURÇA, 2006) e que, no caso brasileiro, carece de mais investimento analítico. Por outro lado, os estudos sobre jovens sem religião no Brasil sugerem que o tipo sem religião resultaria de um conjunto de transformações promovidas pelo processo de secularização que atingiu de diferentes modos as sociedades modernas e que tem produzido formas, muitas vezes ambivalentes, de inter-relação com o campo religioso.

Parte-se da consideração de que a desinstitucionalização religiosa não pode ser analisada de maneira isolada, como um dado autoexplicativo, compreendido simplesmente por meio da gramática secularizaçãodessecularização (BERGER, 1985, 1999). As transformações socioculturais advindas da atual fase da globalização promovem um conjunto de mudanças que alteram as relações dos indivíduos com as instituições, 
ora promovendo uma crítica mais aguda sobre elas, ora buscando novas formas de vínculo. Partindo dessas considerações preliminares, trazemos as trajetórias para o debate aqui circunscrito.

\section{Trajetórias, crenças e relativizações - a desvinculação como processo}

\section{Agnosticismo}

"Eu sou Agnóstico". A firmeza com que Lucas ${ }^{4}$ - um secundarista morador da Baixada Fluminense e ocupante de escola pública - respondeu à pergunta sobre religião impressionou o pesquisador. Com apenas 17 anos, negro, filho de pais com nível médio de escolarização e com herança familiar materna evangélica, Lucas é um caso interessante para pensar as dimensões da associação entre pentecostalismo e pobreza. Conforme pesquisa sobre dados censitários (JACOB et al., 2003), tanto os adeptos do pentecostalismo quanto os indivíduos sem religião residem nas franjas metropolitanas, isto é, nas periferias das grandes cidades Para certificar-se em relação ao conhecimento do jovem sobre o agnosticismo, o pesquisador avançou: "o que significa ser agnóstico para você?" Nesse momento, Lucas delineia os passos de sua trajetória até assumir essa identidade. Filho de mãe evangélica e avó materna católica, ele frequentou a Igreja Batista Renovada com a mãe até aproximadamente sete anos de idade, quando então ela se afastou da Igreja. Uma vizinha com participação na mesma Igreja e habituada a levar os filhos ao templo ampliou o número de crianças com as quais caminhava semanalmente até o local de culto.

Contudo, a trajetória de Lucas na Igreja Batista se encerrou na adolescência, aos 14 anos, quando as dúvidas sobre a fé que professava começaram a inquietá-lo, além do incômodo sentido com a conduta das lideranças de sua Igreja. O jovem passou então a estudar religiões para tentar dar respostas a si mesmo sobre sua identidade e, na ocasião, descobriu-se agnóstico. Ele afirma respeitar as religiões e crenças alheias e condena amigos ateus que criticam as religiões. O rapaz, amante de leitura, incluindo livros de história, mitologia grega e ficção, mostra-se veemente

\footnotetext{
${ }^{4}$ Os nomes são fictícios.
} 
na defesa do direito de crença de cada pessoa, e insiste que a realização pessoal deve ser o critério para as escolhas que daí advêm.

Exatamente por isso, Lucas não concorda com a postura de amigos cristãos que buscam convertê-lo às suas respectivas religiões, ficando escandalizados com seu agnosticismo. $\mathrm{O}$ jovem entende que cada pessoa tem o direito de desejar compartilhar a fé ou a religião com os outros, mas rejeita a atitude proselitista que coloca o interlocutor como um potencial convertido.

Foi interessante notar em seu relato o processo reflexivo no qual Lucas buscou achar uma definição para seu estado de crenças ou não crenças. "Num período de dúvidas eu estava sem saber o que eu era e fiz algumas pesquisas pra não ficar sem saber. Aí eu vi que a palavra que mais se encaixa na minha situação é o agnosticismo."

Três pontos principais podem ser destacados em seu discurso sobre os motivos que o levaram ao agnosticismo. Em primeiro lugar, o jovem estudante passou a discordar da relação de troca entre dízimo e graça divina advogada pelos pastores de sua Igreja. Lucas afirmou que à época não conseguia mais acreditar que os eventos ocorriam do modo que o pastor garantia. Em segundo lugar, seu discurso evidenciou uma dúvida pessoal sobre a eficácia da prece. Haveria mesmo alguém a escutá-lo em seus momentos de recolhimento e de oração? Para ele, o agnosticismo se apresentava como um posicionamento cada vez mais plausível diante das religiões. Por fim, constatou-se sua crítica ao modo como os cristãos agem: "são pessoas bem complicadas de se lidar". Essa conjunção de fatores levou, portanto, Lucas ao agnosticismo.

Com efeito, se, por um lado, ficou evidente sua crítica aos cristãos, por outro, o jovem mostrou-se bastante tolerante ao conhecimento de outros credos, declarando-se "aberto a experiências novas". O candomblé ou a umbanda foram mencionados como religiões que ele visitaria facilmente no intuito de conhecer, mas "sem compromisso", deixando claro que não intenciona estabelecer vínculos religiosos, ao menos por enquanto.

Ainda assim, a flexibilidade diante de outros credos, associada a uma postura reflexiva, é corroborada em sua afirmação sobre convicção de crenças. Para Lucas - cujo hábito de leitura é muito presente - é possível crer em algo que se apresente como plausível historicamente. Desse modo, a ideia de Deus ou deuses não é assumida nem radicalmente rejeitada, o que assegura a sua atitude tipicamente agnóstica. " [...] eu não nego a existência de nenhum, mas também não confirmo a existência de nenhum. Eu não 
acredito nem desacredito. Eu acho que seria antiético porque eu vejo alguns amigos ateus que ficam zombando de Deus [...] e eu acho errado. Eu não faço isso. Se eu não acredito, eu não falo, se eu acredito eu guardo pra mim."

A única manifestação de crença em sua entrevista o aproxima do universo Espírita, embora sua trajetória religiosa não contemple o contato com centros espíritas ou religiões afro-brasileiras. "Agora, questão de espírito eu não sei muito bem, mas eu acho que eu já senti presença de alguma coisa assim. Tanto de ouvir vozes... Uma vez eu tava (sic) parado na casa da minha avó [...] e eu sentia presenças e alguém chamava meu nome, ouvia passos na laje, [sentia] alguém bater no meu ombro e eu não via ninguém, e foi puxão mesmo, e não havia ninguém. Então eu fiquei bem confuso."

Embora tenha sido socializado no universo da Igreja Batista, Lucas posicionou-se de maneira liberal quando o assunto é sexualidade, incluindo virgindade e direitos reprodutivos. Há, contudo, algumas ressalvas relacionadas ao sexo praticado de forma indiscriminada. Em sua visão, a sexualidade deve ser exercida mediante a existência de sentimentos mútuos, numa clara alusão ao amor romântico. Ao final, ressalta a liberdade de cada pessoa sobre o próprio corpo como um critério determinante para o exercício da sexualidade. Os métodos contraceptivos são importantes na visão do jovem agnóstico, ex-evangélico, tanto para prevenção de doenças sexualmente transmissíveis quanto para evitar a gravidez indesejada.

Embora descrente da política representativa, Lucas demonstrou ser um jovem politizado, preocupado com causas públicas, tais como a educação, os baixos salários dos professores e ainda o problema da governança no Brasil, uma vez que sua entrevista ocorreu por ocasião do impeachment da ex-presidente Dilma Rousseff. Sua ação política era exatamente a ocupação de sua escola, demonstrando expectativas de mudança a partir das "lutas" juvenis. Crítico à postura da mãe que defende a volta do regime militar no país, Lucas acredita na mudança que cada pessoa é capaz de promover, mas manifestou pouca credibilidade em mudanças estruturais da sociedade brasileira.

\section{Ateísmo}

A defesa da liberdade de escolha no campo da sexualidade aproxima João, um rapaz de 23 anos, estudante de Economia e morador de Queimados, município situado na Baixada Fluminense, de Lucas, o jovem agnóstico. Ao 
posicionar-se em relação à preservação da virgindade até o casamento, João declara de maneira assertiva: "Eu sou a favor desde que a pessoa queira e eu sou contra se a pessoa for contra. Se a pessoa for contra a virgindade e alguém obrigá-la a ser virgem até o casamento, aí eu sou contra. Porque vai contra o direito de escolha de indivíduo. Agora se a pessoa, por livre e espontânea vontade, quiser ser virgem até o casamento, eu não vejo problema nenhum. A escolha é individual".

$\mathrm{O}$ jovem ateu narra que, antes de assumir essa identidade, frequentou as igrejas evangélicas Deus é amor, Batista, Universal do Reino de Deus e Bete Javé, sendo levado às igrejas por seus pais. Fica evidente aqui a conexão com a teoria que afirma o pluralismo religioso como uma porta aberta também para o ateísmo. (BENDER, 2013).

De modo particular, João sublinhou sua participação na Igreja Universal e relatou o evento dramático que o conduziu ao ateísmo: a cura prometida e não alcançada para o câncer de sua tia, que culminou em óbito. As intensas orações feitas por toda a família e as promessas de cura advindas das "revelações" de membros da Igreja aumentaram suas expectativas em relação à cura não concretizada.

Após essa decepção, João sentiu-se mais livre para descartar crenças religiosas, afastando-se definitivamente da religião. Suas dúvidas e questionamentos ampliaram-se, e ele passou a duvidar de vários elementos do cristianismo, como a existência do céu, inferno e "possessão demoníaca", esse último aspecto fortemente presente na teologia iurdiana.

No processo de desinstitucionalização religiosa, João identificou ao menos dois momentos: no primeiro, sua atitude era de ironia para com as religiões, e o segundo - ao qual denomina "amadurecimento" - o jovem ateu adquire uma percepção diferente, mais tolerante dos fatos, demarcando uma posição de respeito às escolhas individuais. Ele aciona premissas cristãs para justificar sua conduta e visão sobre a humanidade: "não fazer com o outro o que não gostaria que fosse feito consigo mesmo".

Sua perspectiva é otimista sobre o futuro da humanidade na medida em que pontua avanços civilizatórios como aspectos positivos, mas destaca o que seria o lado sombrio das sociedades, sinalizando para aspectos como suicídio, depressão e falta de emprego como sintomas de "adoecimento" social.

O trânsito religioso de seus pais fez com que João sempre tivesse que atender a diferentes demandas das igrejas às quais era levado. Desse modo, fazer orações, cantar ou manifestar-se publicamente nos momentos de 
culto durante a infância ${ }^{5}$ não foram experiências que lhe remetesse boas lembranças. "E pra mim, assim, igreja foi sempre sinônimo de trauma. Trauma que eu digo [de] sempre fazer o que eu não queria por imposição dos outros, por exemplo: cantar lá na frente, as crianças. Eu não gostava de cantar, mas todas as crianças cantavam e não sabiam nenhum hino, mas eu era obrigado a ir lá frente, tímido pra caramba, aí tinha que ir lá na frente e cantar com as crianças. Escola dominical dia de domingo, eles sempre escolhiam uma criança para orar, eu não sabia orar, eu não gostava de orar [...] eu ia obrigado, apesar de acreditar, entendeu?"

O incômodo sentido na infância por ter que atender às solicitações feitas pelos líderes e comunidade religiosa fez com que João passasse a associar a imagem da igreja a algo negativo. No entanto, considera tanto a Igreja Católica quanto as evangélicas como instituições propícias aos que possuem uma espiritualidade, situação na qual ele não se enquadra. Assim, João trata a dimensão espiritual como uma espécie de dom, algo que "a pessoa sente dentro de si", mas que em seu caso não ocorreria.

É importante informar que o jovem ateu é bombeiro militar do estado do Rio de Janeiro e sob o ponto de vista profissional possui estabilidade. A graduação em Economia faz com que tenha um capital social um pouco acima da média, no sentido de ter acesso à informação e leituras críticas sobre a política e economia brasileira. De tal modo, ele afirma tentar influenciar seus amigos que não possuem "uma noção de política muito elevada". João mostrou-se orgulhoso de sua formação e entende ser necessário conscientizar seus amigos politicamente, oferecer opções, mas não "doutrinar".

O discurso de João apresenta uma racionalidade pragmática, baseada em convicções e valores mais universalistas, dentre eles o respeito e a liberdade de escolha.

\section{Sem religião}

Tamires é filha de pai sem religião e mãe evangélica convertida da umbanda. Durante toda a vida, a jovem participou da Igreja Comunidade Evangélica Viver em Cristo, também frequentada por sua mãe. A pergunta sobre qual

\footnotetext{
${ }^{5}$ A Igreja Bete Javé é uma das que organiza o chamado culto kids, em que as crianças são chamadas para apresentações teatrais, orações e cantos no altar.
} 
era a sua religião obteve resposta sintomática em relação à disposição mental da jovem para o campo religioso e as possíveis novas adesões religiosas que poderá vir a fazer. Nesse sentido, a jovem Tamires confirma diagnósticos prévios de que ser sem religião não é uma condição definitiva no Brasil (FERNANDES, 2013), mas pode ser uma identidade provisória, marcada por determinadas circunstâncias práticas da vida. Ao ser questionada sobre qual seria a sua religião, Tamires responde rapidamente sem hesitações: "no momento, sem religião".

A resposta dessa moça de vinte e seis anos, negra, técnica de enfermagem e com nível médio de escolarização assume uma conotação fortemente provisória e circunstancial. Tamires reside também na Baixada Fluminense, em Nova Iguaçu, município onde a adesão pentecostal juvenil tem se mostrado rarefeita (SILVA, 2017).

A trajetória de Tamires, no que tange ao pertencimento institucional religioso, sofreu uma ruptura quando ocorreram desentendimentos com a pastora e esta a expulsou da igreja formalmente, entregando-lhe, inclusive, a carta de expulsão. O motivo do desentendimento relaciona-se com a moralidade mais rígida da igreja e a pastora teria chamado a atenção de Tamires quanto ao uso de determinadas roupas.

Embora manifeste sua crença em Deus, a jovem verbaliza um conjunto de críticas às instituições religiosas. Uma de suas principais críticas está relacionada aos apelos das igrejas em relação ao dinheiro. Com efeito, ela manifestou desprezo pela atitude corriqueira de pedido de dinheiro das igrejas evangélicas, considerando "ridículo" o uso de máquinas de cartão para arrecadação financeira nos templos.

A consideração da jovem sem religião de que outras religiões seriam mais "respeitadoras" do que a evangélica surpreende pelo exemplo que ela traz. Tamires cita a "macumba" - numa alusão a religiões afro-brasileiras - como exemplo de religiões que "respeitam mais os seres humanos". Neste caso, a surpresa reside na subversão da tensão neopentecostalismo x religiões afrobrasileiras, que parece ter se dissipado no relato da jovem. Considere-se a hipótese de que o embate entre evangélicos e afro-brasileiros pode ser mais agudo por parte de líderes pentecostais e neopentecostais do que por parte dos membros dessas igrejas.

Apesar de estar afastada da Igreja, Tamires mantém sua prática de oração matinal e noturna e a justifica por serem esses os instantes em que tem a oportunidade de "conversar com Deus". Sendo assim, percebe-se que a inexistência de vínculo religioso atual não se traduziu na perda de hábitos 
que reforçam a identidade religiosa adquirida por ocasião do vínculo anterior. Na verdade, Tamires está em busca de uma nova denominação, e enquanto o novo vínculo não se estabelece, ela se considera sem religião. O desencanto com a liderança de sua Igreja não a fez desistir de voltar a "pertencer", ainda que possa tecer críticas institucionais mais agudas.

As perspectivas morais e políticas de Tamires mostraram-se menos mantenedoras do status quo e mais questionadoras da ordem política estabelecida. A jovem manifestou-se favorável aos protestos públicos e assumiu que acredita nos efeitos positivos de reivindicações dessa natureza. "[...] como eu sou técnica de enfermagem, esses dias, o Pezão, ele não decretou às $30 \mathrm{~h}$ pra gente, semanal. Então, eu até... entramos num debate lá no trabalho pra ir todo mundo 'pra' rua. Se todos os técnicos de enfermagem parasse [sic] e fosse [sic] pra rua, seria uma manifestação e de repente eles aceitaria [sic] isso [o ajuste da carga horária da categoria]. Porque se todos os técnicos parassem de trabalhar, o hospital não funcionaria."

Tamires condenou ainda a corrupção do Estado e das Igrejas demonstrando uma atitude bastante crítica em relação ao pedido indiscriminado de dinheiro dessas últimas, como mencionado. Sua opinião está relacionada com a credibilidade das instituições e emerge diante do questionamento sobre nível de confiança nas instituições. Para Tamires, "está tudo uma roubalheira; cada dia eles roubam mais. Até nas igrejas estão roubando tudo"!

Em relação a determinados temas relacionados a moralidades ou costumes, Tamires mostrou-se mais liberal em alguns aspectos e mais alinhada com o senso comum em outros. Destarte, posicionouse contrariamente à imposição da virgindade até o casamento e favoravelmente ao uso de métodos contraceptivos. Por outro lado, em relação à homossexualidade, manifestou-se de maneira neutra no sentido de que afirmou não discriminar os homossexuais, mas de valorizar a manutenção da ideia de família tradicional: “Já... em relação à adoção [de filhos por homossexuais], eu já não acho legal, porque assim, tem o pai e a mãe, entendeu? Como a... é difícil...como explicar pra uma criança que você tem dois pais, ou então tem duas mães, entendeu? Eu acho que

\footnotetext{
${ }^{6}$ Luiz Fernando de Souza, conhecido como Luiz Fernando Pezão, era o governador do Estado do Rio de Janeiro em 2016, ano de realização da entrevista.
} 
a cabecinha da criança fica meio que... conturbada. E outro que eu acho supererrado, hoje em dia nas escolas, nas escolas não tem mais 'dia dos pais, dia das mães' é 'dia da família'.".

Uma peregrina religiosa sem religião poderia ser a classificação de Tamires, cujo perfil pode ser o de muitos jovens brasileiros desvinculados das instituições religiosas.

\section{Considerações finais}

No intuito de lançar luzes para a compreensão do perfil de jovens sem religião no Estado do Rio de Janeiro e ampliar o debate sobre desinstitucionalização, a trajetória dos três jovens aqui apresentados permite identificar alguns pontos consonantes. Mas, antes disso, importa ressaltar a novidade da identificação da trajetória de jovens evangélicos que se desinstitucionalizaram religiosamente e que assumiram novas identidades, não seguindo uma rota que implicasse a mera substituição de uma denominação religiosa por outra, após a ruptura com suas respectivas igrejas. Assim, enquanto uns tornam-se ateus ou agnósticos, outros assumem a identidade provisória de sem religião.

A pesquisa tem demonstrado como jovens neopentecostais, moradores nas periferias urbanas possuem trajetórias religiosas plurais, racionalizam suas pertenças e rupturas e constroem argumentos de plausibilidade para a nova identidade assumida, sem vínculos com igrejas, ainda que provisoriamente. Além disso, o ambiente familiar de intenso pluralismo religioso parece não assegurar a permanência dos jovens nas igrejas, mostrando enfraquecimento do vínculo capitaneado pela família de origem.

O jovem Lucas impressionou pela determinação e clareza na adoção da nova identidade agnóstica, após uma trajetória marcada pelo viés religioso, sob influência materna. No entanto, sua "abertura" a novas religiões como forma de conhecimento pode ser um indicador de adesões futuras. A racionalidade reflexiva de sua narrativa abre um campo exploratório que inclui a variável escolaridade e ainda o acesso à educação informal por meio de leituras e palestras. Esse tipo de sociabilidade ilustrada em ambientes nos quais as ofertas educacionais são escassas parece ter sido uma variável relevante em sua escolha pelo agnosticismo.

O ateísmo de João situa-se no debate sobre vocação para a vida religiosa. Em sua percepção, uns a possuem e outros não, o que põe em xeque, a partir de sua visão, a representação da religião como fonte de sentido. 
Embora sua desvinculação institucional tenha sido motivada por decepção com a eficácia do sistema religioso, é interessante perceber o modo como ele reelabora sua escolha, inscrevendo-a numa fórmula mais simples, capaz de conjugar afinidade e dom. Com efeito, sua experiência religiosa pregressa não foi determinante no sentido de garantir a permanência de crenças apreendidas na infância. Uma vez mais, o nível educacional parece ter funcionado como importante variável para a opção desse jovem pelo ateísmo.

Considerando estudos anteriores (FERNANDES, 2013; NOVAES, 2013) Tamires representa boa parte dos jovens brasileiros sem religião: possuem crenças religiosas, mas podem permanecer desvinculados institucionalmente por longo tempo. Em seu caso, a escolaridade média e o menor acesso a opções educacionais informais parece ter funcionado como elemento mantenedor da crença nas instituições religiosas, não obstante suas críticas à denominação de origem e sua experiência traumática de desvinculação.

A jovem técnica de enfermagem é o caso típico na categoria dos sem religião que estariam em intervalo de pertencimento institucional, mas continuam buscando opções plausíveis para a nova adesão. São aqueles desvinculados provisoriamente, mas que mantêm práticas e crenças originárias.

Os depoimentos desses jovens exemplificam ainda aspectos que podem vir a ser explorados entre pentecostalismo e conservadorismo nos costumes, entre jovens residentes em municípios periféricos. Assim, embora os três casos analisados tenham sido formados nas narrativas neopentecostais sobre moralidades e política, mostraram-se críticos aos discursos institucionais, e o trio advogou liberdades de escolha no campo religioso e moral. Eles demonstraram ainda posicionamentos políticos críticos, sem alinhamentos que indicassem a tentativa de manutenção do status quo. No caso de Tamires, a rigidez moral da denominação provocou o seu afastamento.

Note-se que os processos de desinstitucionalização desses jovens se deram por razões distintas, mas guardaram algumas semelhanças, tais como as críticas institucionais e a ênfase no discurso da defesa de direitos e liberdade de escolha em vários campos da vida. Além disso, suas narrativas advogam o respeito ao pensamento divergente como uma regra importante para o bom convívio social.

As análises das diferentes trajetórias juvenis levantam um conjunto 
de questões que poderão ser mais bem exploradas ao final da pesquisa. Contudo, cumpre alinhavar brevemente as pretensões inicialmente expressas.

Em primeiro lugar, o jovem sem religião se apresenta multifacetado, podendo agregar em uma única identidade um posicionamento crítico e, ao mesmo tempo, flexível em relação às denominações religiosas. Em muitos casos, o fato de não estar vinculado a uma igreja revela apenas uma faceta do processo de desinstitucionalização. Este pode comportar rejeição e assimilação; crítica racional e tolerância. Embora algumas crenças religiosas possam ser perdidas no processo, sobretudo as crenças cristãs tenderam a ser mantidas por dois deles, ao passo que João manteve a chamada "regra de ouro": cada um deve tratar o outro como gostaria de ser tratado.

Os três casos aqui analisados ilustram como o neopentecostalismo presente em ambientes periféricos pode coexistir com a mudança de religião entre os jovens, promovendo a desvinculação religiosa em lugar de novas adesões religiosas institucionais. Isso significa dizer que outras variáveis estão compondo as escolhas religiosas ou não religiosas de jovens residentes em municípios pauperizados da cena urbana e que a valorização da liberdade de escolha e da autonomia na configuração da identidade são aspectos do discurso moderno que parece ter peso nos processos de desvinculação religiosa desses jovens.

As trajetórias aqui analisadas sugerem que o nível educacional pode ser uma variável relevante, mas a hipótese precisa ser testada em estudos mais abrangentes. Provavelmente, a presente pesquisa poderá oferecer alguns novos caminhos interpretativos em médio prazo.

Caberia levar em conta ainda que esses jovens ex-evangélicos de vertente neopentecostal relativizaram normas e preceitos de suas denominações a ponto de tornarem-se sem religião, optarem pelo ateísmo ou agnosticismo. No movimento de reinscrição de suas crenças e visões de mundo, demonstraram flexibilidade em relação a alguns costumes e tiveram posicionamentos críticos no que se refere à política e à esfera pública. Desse modo, vimos que Lucas, o jovem agnóstico, estava ocupando escola quando foi entrevistado; as denúncias à exploração econômica nas Igrejas e à corrupção do estado estavam presentes em todas as narrativas, e o trio apresentou posições ponderadas e mais flexíveis em relação à sexualidade e direitos reprodutivos, ainda que a ideia de família nuclear tenha sido defendida por Tamires.

Por fim, os três casos analisados revelam a importância de 
desenvolvermos estudos de natureza qualitativa que possam contribuir para compreender as lógicas e subjetividades de jovens que nasceram em ambiente evangélico. Lucas, João e Tamires tornaram-se, por razões diversas, desinstitucionalizados e críticos de determinadas narrativas religiosas nas quais foram socializados.

\section{Referências}

AUGUSTO, Nuno L.

(2008). A juventude e a(s) política(s): Desinstitucionalização e individualização". Revista Crítica de Ciências Sociais, n. 81, p. 155-177.

ARMSTRONG, Karen. (1999). A History of God, London: Vintage.

BENDER, Courtney.

(2013). Pluralism and Secularism. In: Religion on the Edge. New York, Oxford University Press. p. 137-158.

BERGER, Peter (Ed.).

(1999). The desecularization of the world: a global overview. In: The desecularization of the World: Resurgent Religion and World Politics. Washington, Grand Rapids / Eerdmans.

(1985). O Dossel Sagrado: Elementos para uma sociologia da religião. São Paulo, Paulinas.

BROWN, Desmond.

(1977). Dilemmas of Deinstitutionalization. Sociological Analysis, Vol. 38, n. 2, p. 140-144.

CAMURÇA, Marcelo Ayres.

(2017). 0s Sem Religião no Brasil: Juventude, Periferia, Indiferentismo Religioso e Trânsito entre Religiões Institucionalizadas. Estudos de Religião, v. 31, n. 3, p. 55-70.

FERNANDES, Sílvia.

(2013). Expressões políticas e crenças religiosas de jovens sem-religião. In: Cristina Satiê Pátaro; Fábio André Hahn; Frank Antonio Mezzomo (Orgs.); Instituições e sociabilidades: religião, política e juventudes. Campo Mourão, Fecilcam. p.9-30.

(2012). A (re) construção da identidade religiosa inclui dupla ou tripla pertença. IHU On Line., Disponível em: <http://www.ihu. unisinos.br/entrevistas>. Acesso em 31 de outubro de 2017.

(2011). Marcos definidores da condição juvenil para católicos e pentecostais na Baixada Fluminense - algumas proposições a partir de um survey. Religião \& Sociedade (Impresso). v.31, p.96- 125 .

(2009). Juventude nas Igrejas e fora delas: crenças, percepções da política e (des) vinculações. Tomo (UFS) (Printed), v.14, p.99126.

(2008). Sem Religião e Identidades Religiosas Notas para uma tipologia. Interseções (UERJ) (Printed), v.1, p.31- 46.

(2006). Mudança de Religião no Brasil desvendando sentidos e motivações. São Paulo / Rio de Janeiro, Palavra \& Prece e CERIS.

JACOB, Cesar et. al.

(2003). Atlas da Filiação Religiosa e Indicadores Sociais no Brasil. Rio de Janeiro / São Paulo, Ed. PUC- Rio / Loyola.

LOMBRAÑA, Julián Velarde.

(2011). Razón ilustrada y agnosticismo. Revista Internacional de Filosofía, Suplemento 4, 2011, 287-296. Disponível em: <https://goo. $\mathrm{gl} / \mathrm{tbBzkU>}$. Acesso em 20 de março de 2018. 
MONTERO, Paula; DULLO, Eduardo.

(2014). Ateísmo no Brasil - da invisibilidade à crença fundamentalista. Novos estudos CEBRAP, 100, São Paulo, 2014. p.57-79.

NOVAES, Regina. Jovens sem religião: sinais de outros tempos.

(2013). In: Renata Menezes; Faustino Texeira (Orgs.); Religiões em Movimento: o Censo de 2010. Petrópolis, Vozes. p.175-190.

(2006). Os jovens, os ventos secularizantes e o espírito do tempo. In: Renata Menezes; Faustino Texeira (Orgs.); As religiões no Brasil - continuidades e rupturas. Petrópolis, Vozes. p.135-160.

RODRIGUES, Denise S.

(2010). Juventude sem religião: uma crise do pertencimento institucional no Brasil. Teoria \& Sociedade (UFMG), v. 18, p. 66-93.
SILVA, Ana Raquel P.

(2017). Periferia, pentecostalismo e juventude: práticas e pertenças dos jovens da $1^{\text {a }}$ igreja Evangélica Assembleia de Deus em Santa Rita, Nova Iguaçu - RJ. Trabalho de conclusão de curso apresentado ao curso de Geografia da UFRRJ. Nova Iguaçu, Instituto Multidisciplinar.

TAVARES, Fátima R. Gomes; CAMURÇA, Marcelo Ayres.

(2006). Religião, família e imaginário entre a juventude de Minas Gerais. Ciencias Sociales y Religion, n. 8, p. 99-119.

\section{Recebido em}

abril de 2018

Aprovado em

novembro de 2018 